\title{
NORMATYWNA AKTUALIZACJA
}

\begin{abstract}
Streszczenie. Artykuł jest recenzją i krótkim komentarzem do tekstów dotyczących normatywności i zebranych w dziale nazwanym Normatywność. 'Update' i opublikowanych w jednym z numerów czasopisma Avant. Autor stara się wykazać, że często rozróżniane porządki myślenia o normatywności - moralny i pozamoralny, na poziomie ludzkich praktyk są ze sobą ściśle powiązane. Głównym celem artykułu jest wyraźne wyłuszczenie i skomentowanie aktualizacji podejścia do normatywności proponowanych przez publikujących w Avancie badaczy.
\end{abstract}

Słowa kluczowe: normatywność, norma społeczna, aktualizacja, moralność

W jednym z ostatnich numerów czasopisma $A v a n t^{1}$ ukazał dział o nietuzinkowej nazwie: Normatywność. 'Update'. Komentowanie tekstów zawartych w tym dziale zacząć należy od zarysowania problemu, który zauważyli sami autorzy, czyli braku jednej, jasnej definicji terminu „normatywność”. Pojęcie to można rozważać na poziomie etyki, prawa, logiki, metodologii, filozofii języka, epistemologii, filozofii umysłu czy metaetyki. Sytuację tą dobrze pokazuje cytowany przez Dominikę Dzwonkowską fragment artykułu Michała Piekarskiego, w którym stwierdza on, że ,już pobieżna lektura opracowań dotyczących normatywności czy szybki przegląd baz bibliograficznych zawierających jako jedno ze słów kluczowych termin «normatywność», prowadzi do spostrzeżenia, że nie można mówić o niej

1 Avant to czasopismo poświęcone bieżącym trendom w badaniach interdyscyplinarnych, skoncentrowane na kognitywistyce, antropologii poznawczej i kulturowej, społecznych badaniach nad nauką, jak i badaniach nad sztuką. Celem założycieli i prowadzących czasopismo jest działalnie „przeciwko zmurszeniu filozofii i dziwaczności nauki”. Avant. Trendy w badaniach interdyscyplinarnych, czasopismo wydawane przez: Ośrodek Badań Filozoficznych w Warszawie, ISSN: 2082-6710, strona internetowa: avant.edu.pl. 
tylko w jednym sensie"2. W tekstach umieszonych w omawianym numerze Avantu także nie odnajdujemy jednego określenia, którym moglibyśmy zdefiniować normatywność. Jednakże w żadnym razie nie uważam tego za błąd w sztuce. Pokazuje to jedynie, z jak trudną i rozległą tematyką mierzyli się autorzy, którzy - mimo tych trudności - w stosunkowo jasny sposób wyrażali swoje poglądy obejmujące referowane zagadnienia.

Publikacje zawarte w tym dziale uporządkowane zostały w trzy kategorie: artykuły, komentarze i przekład. Co warte uwagi, teksty te możemy uznać za interdyscyplinarne (albo nawet nawiązując do programu Stanu Rzeczy - antydyscyplinarne3). Czytając kolejne artykuły przechodzimy, od fenomenologii i kognitywistyki przez ekologię poznania społecznego aż do feminizmu. Do tego wszystkiego otrzymujemy przekład tekstu Sebastiana Mudersa O pojęciu normatywności w ocenie zaburzenia umystowego oraz trzy krótkie, ale esencjonalne komentarze do wybranych zagadnień lub artykułów dotyczących normatywności. Wszystko to poprzedzone jest krótkim wstępem Aleksandry Derry i Witolda Wachowskiego otwierającym i niejako komentującym całą dyskusję.

Pierwszy artykul Normatywnośc antycypacji a normatywność predykcji. Dwa podejscia: fenomenologia i przetwarzanie predykcyjne jest autorstwa wspominanego już wcześniej Piekarskiego. Jest to tekst niezwykle obszerny, a co najważniejsze precyzyjnie traktujący temat. Jednak wymaga dużych kompetencji terminologicznych, a wynika to $\mathrm{z}$ tego, że $\mathrm{w}$ ramach tematyki będącej na pograniczu

2 M. Piekarski, One or many normativities?, Studia Philosophiae Christianae 54(2018)1, 5-24. DOI: 10.21697/spch.2018.54.1.11. w druku. Cyt. za: D. Dzwonkowska, Normatywność etyki cnót środowiskowych na przykładzie etyki Ronalda Sandlera. Komentarz, Avant 8(2017)3, 100, DOI: 10.26913/80302017.0112.0005.

3 Redaktorzy czasopisma Stan Rzeczy opisują jego profil jako antydyscyplinarny zob. stanrzeczy.edu.pl; B. Brzostek, W. Wachowski, Do rzeczy - antydyscyplinarnie. Recenzja „Stanu Rzeczy” i refleksje recenzentów, Avant 4(2013)1, 292-300, DOI: 10.12849/40102013.0106.0015. 
dyscyplin - z którymi zmaga się autor - nie wypracowano jeszcze wspólnego słownika. To sprawia, że publikacja jest trudniejsza do przyswojenia, jednak mimo tych komplikacji warto się w nią wczytać.

Piekarski w swoim tekście zajmuje się tematyką, która w polskojęzycznej literaturze jest czymś nowym: zestawia teorię przetwarzania predykcyjnego $\mathrm{z}$ fenomenologią. Celem, który stawia sobie autor, jest zastanowienie się nad tym, które ze stanowisk (transcendentalne czy naturalistyczne) oferuje bogatsze i pełniejsze wyjaśnienie normatywnych własności mechanizmów antycypacyjnych obecnych w procesach percepcyjnych. Piekarski stwierdza, że „porównanie obu tych ujęć jest kluczowe dla wielu dyskusji prowadzonych w obrębie współczesnej filozofii. Jedną z nich jest dyskusja nad normatywnością, która ogniskuje się wokół sporu naturalizmu $\mathrm{z}$ antynaturalizmem. Niniejsze badania stanowią głos w tej debacie"4.

Tak jak już wcześniej wspomniano, Piekarski wskazuje na pewne trudności związane z niejednoznacznością terminu „normatywność". Jednak na potrzeby swojego artykułu, powołując się na Marka H. Bickharda i Karla J. Fristona ${ }^{5}$, przyjmuje, że: „normatywna jest taka własność, która jest konstytutywna dla kontroli zachowania (działania) oraz struktury i treści wewnętrznego dla danego systemu poznawczego modelu świata. Jest to pewne uszczegółowienie szerokiego rozumienia normatywności. Tak rozumianą normatywność należy łączyć przede wszystkim z funkcjami bądź mechanizmami realizowanymi przez dany system, podmiot czy organizm. Nazwę ją

4 M. Piekarski, Normatywność antycypacji a normatywność predykcji. Dwa podejścia: fenomenologia i teoria przetwarzania predykcyjnego, Avant 8(2017)3, 22, DOI: 10.26913/80302017.0112.0001.

5 M. Bickhard, Process and Emergence: Normative Function and Representation, w: Process Theories. Crossdisciplinary studies in dynamic categories, red. J. Seibt, Dordrecht 2003, 121-155. DOI: 10.1007/978-94-007-1044-3_6; Tenże, The interactivist model, Synthese 3(2009)166, 547-591. DOI: 10.1007/s11229-008-9375-x; K.J. Frison, The free-energy principle: a rough guide to the brain?, Trends Cogn Sci. 13(2007)7, 293-301. DOI: 10.1016/j. tics.2009.04.005. 
normatywnością pierwotną"6. Drugim typem normatywności wyróżnionym przez autora jest normatywność weredyczna, którą Piekarski definiuje następująco: „dana hipoteza (predykcja) jest normatywna w tym sensie, że zostaje potraktowana jako obiektywnie ważna. Znaczy to, że jej przyjęcie zobowiązuje organizm do takiego zachowania, które wynika z przyjęcia prawdziwości danej hipotezy"7. Najprościej rzecz ujmując: normatywność pierwotna warunkuje normatywność weredyczną. Pierwsza dotyczy samej możliwości działania, natomiast druga dotyczy wyboru odpowiednich działań. Już nawet to niezwykle skrótowe omówienie idei zawartych w tym artykule wskazuje, że dla Piekarskiego normatywność wykracza poza moralność i konwencje obyczajowe. Ostatecznie autor sam stwierdza, że „prezentowane tutaj ujęcie normatywności odbiega od potocznego rozumienia tego terminu w kategoriach obowiązku czy powinności moralnej bądź ontologicznej"8.

Piekarski w toku swoich analiz, odwołując się między innymi do filozofii Edmunda Husserla, wykazuje normatywny charakter antycypacji analizowanych przez fenomenologię. W dalszej części stara się pokazać, że predykcje pełnią określone normatywne funkcje w procesach percepcyjnych opisywanych w ramach koncepcji przetwarzania predykcyjnego. Natomiast na koniec uzasadnia tezę, według której analizy mechanizmów normatywnych przeprowadzane przez badawczy przetwarzania predykcyjnego są bardziej efektywne i pozwalają na pełniejsze wyjaśnienie normatywności niż ma to miejsce w fenomenologii.

Autor kończy swój tekst, wydawałoby się, prostą, ale jednak wartą podkreślenia hipotezą badawczą mówiącą, że „normatywne intuicje

6 M. Piekarski, Normatywność antycypacji a normatywność predykcji. Dwa podejścia: fenomenologia i teoria przetwarzania predykcyjnego, art. cyt., 24.

7 Tamże, 25.

8 Tamże, 26. 
dotyczące świata i innych podmiotów wywodzą się wprost z doświadczenia percepcyjnego świata".

Drugi artykuł umieszczony w tym dziale także wydaje się wnosić do polskojęzycznego spektrum naukowego nową perspektywę badawczą. Wachowski w swoim tekście, zatytułowanym Jak dziataja rzeczy spoteczne. Poznanie, normatywność i dizajn dla mas, analizuje wątek usytuowania artefaktów społecznych w praktykach normatywnych z perspektywy ekologii poznawczej i - co ciekawe - jednocześnie teorii dizajnu. Jednym $z$ największych walorów tego studium jest inkluzywny język, który nawet niezbyt zaznajomionemu czytelnikowi umożliwia zrozumienie podstawowych tez publikacji. Jest to zgodne z poglądem Elizabeth Dunn, która uważa, że pisanie tekstów naukowych przystępnym dla odbiorców językiem jest najlepszą drogą do poszerzenia odbiorców i zainspirowania kolejnych pokoleń ${ }^{10}$.

Dla uporządkowania warto zaznaczyć, że normatywność jest ujmowana w tym tekście tak szeroko (być może dla wielu czytelników zbyt szeroko), że obejmuje również normalizację przemysłową, na której autor skupił dużą uwagę.

Wachowski w swoim artykule odwołuje się do teorii dizajnu ${ }^{11}$. $\mathrm{Z}$ pewnością jest to termin tak powszechnie używany, że każdy ma z nim jakieś skojarzenie. Gdy jednak mowa o tekście naukowym, sytuacja nie wydaje się tak oczywista. Czym jest ów dizajn i w jakim celu pojawia się w artykule? Autor w jednym z przypisów w taki sposób odpowiada na to pytanie: „Posługuję się tutaj określeniem »dizajn«, ponieważ jego rozumienie wykracza poza synonim projek-

9 Tamże, 50.

10 Zob. A. Leyk, Między produkcją naukową a krytyką społeczną, czyli jak dziś uprawiać nauki społeczne. Rozmowa z Elizabeth Dunn, Stan Rzeczy 6(2014), 88-96.

11 Więcej na ten temat zob. A. Cieślikowa, Design czy dizajn?, http://www.2plus3d.pl/ artykuly/design-czy-dizajn [dostęp: 01.03.2018]; A. Głutkowska-Polniak, Dizajn w kontekście estetyki. Jego początki, przeobrażenia i konotacje, Katowice, 2017; D. Norman, Wzornictwo i emocje. Dlaczego kochamy lub nienawidzimy rzeczy powszechnie, tłum. z ang. D. Skalska-Stefańska, Warszawa 2015. 
towania i wzornictwa, gdyż dotyczy zarówno czynności projektowania, wzoru czy modelu, jak i samej realizacji. Z drugiej strony - taki termin jako »wzornictwo« czy »wzornictwo przemysłowe« nie wydaje się odpowiedni na określenie projektowania interakcji między odbiorcami a wytworami filmowymi, muzycznymi itd."12. Wydaje się, że taka perspektywa w swoisty sposób ożywia, często zbyt teoretyczną, dyskusję filozoficzną.

Autor próbuje w prosty sposób wykazać, że „realizacja codziennych praktyk normatywnych nie zachodzi ponad czy obok materialnej sfery naszej codzienności, ale w interakcji z nią"13. Jednocześnie mamy do czynienia z odgórną normalizacją naszej przestrzeni życiowej. To powoduje, że jesteśmy przez nasze otoczenie jakby częściowo „wyręczani”, minimalizuje się naszą potrzebę refleksji nad użyciem danego znormalizowanego przedmiotu. Przykładem może być przytoczony przez Wachowskiego długopis, który natychmiastowo przed swoim użytkownikiem odkrywa mechanizm wysuwania i wsuwania piszącej końcówki. Warto też zwrócić uwagę na trochę bardziej skomplikowany przykład, jakim są drzwi. W takim wypadku pojawia się wiele czynników mogących mieć istotne znaczenie - od samego zlokalizowania drzwi aż do klamki, jaka została przy nich zamocowana. To wszystko powoduje, że część ludzi może być lub może się czuć w pewien sposób wykluczona (czy to ze względu na lokalizację, czy też na wysokość usytuowania klamki, czy wreszcie różnego rodzaju zabezpieczenia selekcjonujące użytkowników).

Ze względu na ograniczenia ramowe recenzji nie mogę tutaj szerzej omówić tez zawartych w tym artykule. Na koniec chciałbym jedynie raz jeszcze powtórzyć główną tezę stawianą przez autora, która odczytuję następująco: społeczny charakter artefaktów powszechnego użytku oraz związane $\mathrm{z}$ nim wprowadzenie znormalizowanych

12 W. Wachowski, Jak działają rzeczy społeczne. Poznanie, normatywność i dizajn dla mas, Avant 8(2017)3, 59, DOI: 10.26913/80302017.0112.0002.

13 Tamże, 65. 
sposobów ich eksploatacji i przejęcie części odpowiedzialności za skutki tej eksploatacji przez projektantów, producentów i dystrybutorów powoduje, że opisując praktyki normatywne, w których używa się znormalizowanych artefaktów, trudno oddzielić wśród nich praktyki moralne od innych. Wszystkie one muszą mierzyć się z „oporem” fizyczności elementów danego otoczenia, w którym są realizowane. Według Wachowskiego, z którym się zgadzam (jeśli dobrze go odczytuję), dizajn powinien stanowić przestrzeń systematycznej optymalizacji życia społecznego i jednostkowego.

Trzeci z artykułów prezentowanych w tym dziale -,Król jest w ciąży". Androgynicznośc a męska norma w literackim eksperymencie Ursuli K. Le Guin - omawia sferę normatywności z zupełnie innej strony. W tym tekście Marzena Adamiak na przykładzie projektu amerykańskiej pisarki Ursuli K. Le Guin zastanawia się nad genderowym uwikłaniem kategorii androgyne i możliwością jej nieuprzedzonego wypowiedzenia, a także nad ewentualną rolą literatury science fiction $\mathrm{w}$ tego typu przedsięwzięciach.

Adamiak w swoim artykule w ciekawy sposób wprowadza czytelników w filozoficzne meandry powieści Le Guin ze szczególnym uwzględnieniem androgyniczności. Udowadnia w ten sposób, że naukowcy nie muszą, a wręcz nie powinni zamykać się w wieży z kości słoniowej i dyskutować tylko między sobą, bez otwierania się na nowe, ożywcze spojrzenie. Częste odwołania do literatury popularnej zdecydowanie poprawiają przyswajalność tekstu i sprawiają, że staje się on ciekawszy. Zresztą podobną tezę stawia autorka tekstu, w jednym z ostatnich akapitów stwierdzając, że „literatura fantasy i science fiction odgrywa w tym wszystkim szczególną rolę, ponieważ daje przestrzeń do swobodnej gry wieloma alternatywnymi wizjami funkcjonowania w różnych wymiarach: jednostkowym, relacyjnym, kulturowym, społecznym, etycznym, czy gospodarczym, pozwalając tym samym na rozmontowywanie tradycyjnych, 
utrwalonych wzorców kulturowych, również tych dotyczących płci i seksualności” ${ }^{14}$.

Kwestią wartą podkreślenia jest to, że artykuł jest jedynie wstępem do dyskusji. Wydaje się, że autorka z premedytacją wprowadza pewne zagadnienia związane z płcią czy androgynicznością, jednak w żaden sposób nie ocenia tej postawy psychicznej z punktu widzenia moralności. Stara się pisać z neutralnego, naukowego punktu widzenia. Dla jednych czytelników może być to wada, dla innych korzyść. Osobiście uważam, że może to tylko zachęcić do samodzielnego przeczytania powieści Ursuli K. Le Guin ${ }^{15}$ i wypracowania swojego zdania.

Kolejną część zapowiadanej przez redaktorów Avantu aktualizacji podejścia do pojęcia normatywności stanowi przekład tekstu $\mathrm{Mu}-$ dersa: Opojęciu normatywności wocenie zaburzenia umystowego. Jest to tekst bardzo krótki i bardzo ciekawy. Autor mierzy się w nim z tezą pozostawioną przez Marco Striera ${ }^{16}$, według której „zaburzenia umysłowe musimy określać na poziomie umysłowym, a więc nigdy nie będziemy w stanie przedstawić ich w czysto fizycznym ujęciu" 17 . Ze względu na niewielką objętość, ale zarazem dużą zawartość merytoryczną tekstu trudno o krótkie i precyzyjne wyłożenie głównych myśli tego autora. Najprościej byłoby zachęcić do przeczytania tego tekstu, jednak postaram się chociaż w kilku słowach oddać tezę Mudersa. Twierdzi on, że fakt, iż zaburzenia umysłowe posiadają pewien element normatywny, nie musi ani wcale oznaczać, że są one objaśniane wyłącznie na poziomie umysłowym czy też nie mogą być określane obiektywnie, ani że istnieją czy są rozpoznawane jedyne w stosunku do norm kulturowych. Wydaje się, że zaprezentowana

14 M. Adamiak, „Król jest w ciąży”. Androgyniczność a męska norma w literackim eksperymencie Ursuli K. Le Guin, Avant 3(2017), 88, DOI: 10.26913/80302017.0112.0003.

15 U.K. Le Guin, Lewa ręka ciemności, tłum. z ang. L. Jęczmyk, Katowice 2011.

16 M. Stier, Normative preconditions for the assessment of mental disorder, Frontiers in Psychology 4(2013), 611. DOI: 10.3389/fpsyg.2013.00611.

17 S. Muders, O pojęciu normatywności w ocenie zaburzenia umysłowego, tłum. z ang. P. Nowakowski, Avant 8(2017)3, 94. 
przez autora tekstu krytyka podejścia Striera jest o tyle skuteczna, że nie tylko podważa jego badania, ale także proponuje pozytywny (i to nie w sensie normatywnym) projekt.

Dział uzupełniają trzy komentarze (choć może trudno to nazwać uzupełnieniem, gdyż stanowią one prawie połowę omawianej treści). Uważam, że komentowanie komentarzy jest nie tylko trudne, ale i niepotrzebne. Dlatego też w tym miejscu chcę jedynie zakreślić tematykę, którą podejmują autorzy tych tekstów.

W pierwszym z komentarzy Dominika Dzwonkowska, odwołując się do koncepcji Ronalda Sandlera, sugeruje, że etyka cnót środowiskowych może być etyką normatywną. Autorka uważa, że aretologia nie musi być jedynie uzupełnieniem etyk normatywnych, ale może być traktowana jako specyficzny przypadek etyki normatywnej. Największą zaletą tego tekstu jest ład, który wprowadza w rozróżnienia koncepcji etycznych. Dzwonkowska wykazuje się skrupulatnością przy dobrze słów i stara się uporządkować często mylnie odczytywane pojęcia.

Kolejny tekst jest komentarzem do artykułu Explaining Contradictory Relations Between Risk Perception and Risk Taking ${ }^{18}$, omawiającego wyniki badania dotyczącego podejmowania ryzykownych zachowań seksualnych przez młodzież w wieku 14-18 lat. Jak relacjonuje Michał Obidziński „celem przeprowadzonego badania było wykazanie, skąd bierze się paradoksalna korelacja postrzegania zagrożenia i podejmowania ryzykownych zachowań która zdaje się być jednocześnie pozytywna i negatywna" ${ }^{19}$. Autorzy omawianej w komentarzu publikacji stawiają hipotezę, iż rozróżnienie większej liczby poziomów ryzyka prowadzi do bardziej ryzykownego

18 B. Mills, V.F. Reyna, S. Estrada, Explaining contradictory relations between risk perception and risk taking, Psychological Science 19(2008)5, 429-433.

19 M. Obidziński, Co badania prowadzone w metodologii teorii rozmytego śladu moga powiedzieć nam o normatywności? Komentarz do artykułu "Explaining Contradictory Relations Between Risk Perception and Risk Taking”, Avant 8(2017)3, 111. DOI: 10.26913/80302017.0112.0006. 
zachowania. Odwołując się do tych badań, a także analizując teorię rozmytego śladu, Obidziński stwierdza, że może ona posłużyć do stawiania sugestii dotyczących normatywności. Jednak, jak zaznacza sam autor, hipoteza ta wymaga dopracowania i dalszych badań.

Tekst zamykający ten dział to komentarz Andrzeja Waleszczyńskiego do dyskusji o intencjonalności działania. Usytuowanie tego tekstu na końcu jest, moim zdaniem, posunięciem bardzo trafionym, gdyż w swoisty sposób podsumowuje on dotychczasowe rozważania. Mam tu na myśli przede wszystkim podkreślenie możliwości istnienia normatywności moralnej i poza-moralnej, co - czasami między wierszami - można wyczytać z wcześniejszych tekstów. Wracając do komentarza Waleszczyńskiego: warto zwrócić uwagę na jego krytykę twierdzenia Joshuy Knobe’a, według którego nawet jeżeli uznamy człowieka za istotę na wskroś moralną, to nie oznacza jeszcze, że nie można rozróżnić porządku normatywnego moralnie od normatywnego poza-moralnie. Autor tekstu zamykającego dział uważa, że „to właśnie umiejętność rozróżniania, do którego z rodzajów normatywności odnoszą się stawiane pytania i wskazania warunków w nim obowiązujących, decydowałaby o wydawanych sądach" ${ }^{20}$.

W podsumowaniu warto odnieść się do tekstu wstępnego, w którym redaktorzy Avantu stwierdzają, że normatywność jest tą domeną filozofii, która jak żadna inna wymaga aktualizacji. Derra i Wachowski zaznaczają także, że prezentowany zbiór tekstów nie rości sobie pretensji do bycia systematycznym przeglądem badań nad normatywnością. Omawiany dział ma być czymś w rodzaju wycinka współczesnej mapy napięć problemowych i ujęć związanych $\mathrm{z}$ takimi badaniami. Wydaje się, że zapowiedzi te znajdują swoje odzwierciedlenie w tekstach, z którymi zapoznają się czytelnicy. Są one zróżnicowane pod każdym względem, zarówno jeśli chodzi o tematykę, metodologię, jak i formę tekstu (artykuły, komentarze

20 A. Waleszczyński, Dwa porządki normatywne. Komentarz do dyskusji o intencjonalności działania, Avant 8(2017)3, 115. DOI: 10.26913/80302017.0112.0007. 
i opinia). Zresztą właśnie tego mają prawo oczekiwać czytelnicy Avantu, gdyż - jak możemy przeczytać na stronie internetowejprogramowo jest to czasopismo awangardy filozoficzno-naukowej, poświęcone bieżącym trendom w badaniach interdyscyplinarnych, skoncentrowane na kognitywistyce, ale również na badaniach nad nauką, techniką i społeczeństwem oraz badaniach nad praktyką artystyczną. Wydaje się, że bez większego problemu teksty załączone w dziale Normatywnośc. 'Update' wpisują się taką tematykę.

Jednak mimo całej różnorodności, jaką bez wątpienia cechuje się ten dział, zauważam kilka cech wspólnych, które można uznać za podstawę tej publikacji. Elementem, na który zwracają autorki i autorzy recenzowanych publikacji, jest zaakcentowanie tego, że o normatywności można myśleć na dwóch, powiązanych ze sobą poziomach: moralnym i poza-moralnym. Jednakże czymś, co wyróżnia omówione teksty, jest zwrócenie uwagi na konieczność aktualizacji. Nawet jeśli autorzy nie piszą tego wprost, to z tego, jak odnoszą się do dotychczasowych badań, widać, że podejście do normatywności wymaga tytułowego update’u. Co ważne, czytelnicy Avantu nie zostają pozostawieni z samą diagnozą i otrzymują kilka ciekawych propozycji. Większość z nich wymaga dalszych prac i dyskusji, dlatego też - nie pozostaje nic innego, jak zastosowanie się do zalecenia Derry oraz Wachowskiego i przeczytanie zrecenzowanych powyżej tekstów jeszcze przed nadejściem kolejnej zimy.

\section{BIBLIOGRAFIA}

Adamiak M., „Król jest w ciąży”. Androgynicznośc a męska norma w literackim eksperymencie Ursuli K. Le Guin, Avant 8(2017)3, 77-92. DOI: 10.26913/80302017.0112.0003.

Bickhard B., Process and Emergence: Normative Function and Representation, w: Process Theories. Crossdisciplinary studies in dynamic categories, red. J. Seibt, Springrt, Dordrecht 2003, 121-155. DOI: 10.1007/978-94-007-1044-3_6.

Bickhard B., The interactivist model, Synthese 3(2009)166, 547-591. DOI: 10.1007/ s11229-008-9375-x. 
Brzostek B., Wachowski W., Do rzeczy - antydyscyplinarnie. Recenzja „Stanu Rzeczy" i refleksje recenzentów, Avant 4(2013)1, 292-300.

Cieślikowa A., Design czy dizajn?, http://www.2plus3d.pl/artykuly/design-czy-dizaj.

Dzwonkowska D., Normatywność etyki cnót środowiskowych na przyktadzie etyki Ronalda Sandlera. Komentarz, Avant 8(2017)3, 99-108. DOI: 10.26913/80302017.0112.0005.

Frison K.J., The free-energy principle: a rough guide to the brain?, Trends Cogn Sci. 13(7)2007, 293-301. DOI: 10.1016/j.tics.2009.04.005.

Głutkowska-Polniak A., Dizajn w kontekście estetyki. Jego początki, przeobrażenia $i$ konotacje, Uniwersytet Śląski, Katowice 2017.

Le Guin U.K., Lewa ręka ciemności, tłum. z ang. L. Jęczmyk, Książnica, Katowice 2011.

Leyk A., Między produkcją naukowa a krytyka spoteczna, czyli jak dziśuprawiaćnauki spoteczne. Rozmowa z Elizabeth Dunn, Stan Rzeczy 6(2014), 88-96.

Mills B., Reyna V.F., Estrada S., Explaining contradictory relations between risk perception and risk taking, Psychological Science 19(2008)5, 429-433.

Muders S., O pojęciu normatywności w ocenie zaburzenia umystowego, tłum. $\mathrm{z}$ ang. P. Nowakowski, Avant 8(2017)3, 93-98. DOI: 10.26913/80302017.0112.0004.

Norman D., Wzornictwo i emocje. Dlaczego kochamy lub nienawidzimy rzeczy powszechnie, tłum. z ang. D. Skalska-Stefańska, Arkady, Warszawa 2015.

Obidziński M., Co badania prowadzone w metodologii teorii rozmytego śladu mogq powiedzieć nam o normatywności? Komentarz do artykutu "Explaining Contradictory Relations Between Risk Perception and Risk Taking”, Avant 8(2017)3, 109-117. DOI: 10.26913/80302017.0112.0006.

Piekarski M., Normatywność antycypacji a normatywność predykcji. Dwa podejścia: fenomenologia i teoria przetwarzania predykcyjnego, Avant 8(2017)3, 25-56. DOI: 10.26913/80302017.0112.0001.

Piekarski M., One or many normativities?, Studia Philosophiae Christianae 54(2018)1, 5-24. DOI: 10.21697/spch.2018.54.1.11.

Stier M., Normative preconditions for the assessment of mental disorder, Frontiers in Psychology 4(2013), artykuł 611. DOI: 10.3389/fpsyg.2013.00611.

Wachowski W., Jak dziataja rzeczy spoteczne. Poznanie, normatywnośc i dizajn dla mas, Avant 8(2017)3, 57-75. DOI: 10.26913/80302017.0112.0002.

Waleszczyński A., Dwa porzadki normatywne. Komentarz do dyskusji o intencjonalności dziatania, Avant 8(2017)3, 119-128. DOI: 10.26913/80302017.0112.0007. 


\section{NORMATIVE UPDATE}

Abstract. The article is a review and a short commentary on texts about normativity collected in a section called Normativity. Update and published in one of the issues of the Avant journal. The author tries to show that the often differentiated orders of thinking about normativity - moral and non-moral, at the level of human practices are closely related. The main purpose of the article is to explicitly enumerate and comment on the updating of the normativity approach proposed by scholars publishing in Avant journal.

Keywords: normativity, social norm, update, morality

MıKOŁAJ RACZYŃSKI

mikola.raczynski@gmail.com

Uniwersytet Warszawski, Instytut Filozofii

Krakowskie Przedmieście 3, 00-047 Warszawa

DOI: 10.21697/spch.2018.54.2.15 